"Mircea cel Batran" Naval Academy Scientific Bulletin, Volume XIX - 2016 - Issue 2 The journal is indexed in: PROQUEST / DOAJ / Crossref / EBSCOhost / INDEX COPERNICUS / DRJI / OAJI I JOURNAL INDEX I I2OR / SCIENCE LIBRARY INDEX / Google Scholar / Academic Keys/ ROAD Open Access I Academic Resources / Scientific Indexing Services / SCIPIO / JIFACTOR

\title{
PRACTICE DOESN'T MAKE PERFECT; PERFECT PRACTICE MAKES PERFECT
}

\author{
Delia LUNGU ${ }^{1}$ \\ Laura CIZER ${ }^{2}$ \\ ${ }^{1}$ Associate Professor, PhD. Department of Navigation and Maritime and River Transport, Faculty of \\ Navigation and Management, "Mircea cel Batran" Naval Academy, Constanta, Romania \\ ${ }^{2}$ Lecturer, PhD. Department of Electrical Engineering and Naval Electronics, Faculty of Marine Engineering, \\ "Mircea cel Batran" Naval Academy, Constanta, Romania
}

\begin{abstract}
Much has been discusses about the importance of writing a lesson plan; nevertheless, this topic will never be obsolete and good teachers will always consider the subject as an important issue in their teaching career. There are teachers who believe that writing a lesson plan is important just for young teachers who need to have a clear idea about what they are going to do in class, while writing a lesson plan by experienced teachers is a waste of time as they already have taught the subject lots of times and know exactly what they have to do about any topic. It has also been stated that not all planned lessons are excellent ones and not all unplanned lessons are a disaster, but even a bad lesson will be less bad if planned, and even a great lesson can be greater with a plan.

The aim of this paper is to discuss the importance of writing lesson plans by analyzing the benefits of a good lesson plan and their impact on teachers' development. The topic is also part of a series of sessions presented in teacher training seminars in which the authors have participated as trainers.
\end{abstract}

Keywords: good versus poor lesson plan, common mistakes, teachers, students

\section{INTRODUCTION}

There is consistent evidence that teachers are still the most important school-based factor in determining learning outcomes, second only to what students bring to school.

Preparing future teachers with the right skills is the core activity in teacher training in universities and colleges where future teachers should be equipped with subject knowledge and teaching and pedagogical skills, that can provide relevant guidance to promote effective practice and support improvement. Nevertheless, regardless of how well prepared the future teachers leave universities, once they start teaching, constant training should be provided to ensure that they stay up to date with the latest developments in the field of education, be it in the area of academic theory or advanced technology. Teacher training should be adjusted to the field of teaching and thus, the focus should be placed either on general or specialized English. Still, there are a few topics which are of general interest regardless of the specialization and, among them a key role is played by Lesson planning. There are different ways in which a session about how to write a good lesson plan can be designed.

\section{METHOD}

The model followed in this article is the one offered in a series of sessions presented in teacher training seminars in which the authors have participated as trainers. Furthermore, the model proposed will answer several questions

(c) 2015. This work is licensed under the Creative Commons Attribution-Noncommercial-Share Alike 4.0 License. with regard to why lesson plans should be written, it will try to underline some of the characteristics of good versus poor lesson plans, will discuss the components that have to be included in a good lesson plan and will end with some common mistakes done when writing a lesson plan.

Why should lesson plans be written?

There are several reasons which could answer this question and they take into account both the teacher and the students.

\section{A good lesson plan:}

- has a positive impact on both the teacher and the learner;

- gives confidence to the teacher;

- helps teachers to be clear about what they want to teach;

- clarifies the teacher's decisions about strategies and methods employed to help students advance systematically towards learning goals;

- may play the role of a reminder for teachers when they get distracted;

- frames the lesson giving it an overall shape;

- builds on previous teaching and prepares for coming lessons;

- structures the lesson and helps the students to better assimilate the new information;

- helps teachers to keep track of what works and what does not work in class. 
"Mircea cel Batran" Naval Academy Scientific Bulletin, Volume XIX - 2016 - Issue 2 The journal is indexed in: PROQUEST / DOAJ / Crossref / EBSCOhost / INDEX COPERNICUS / DRJI / OAJI I JOURNAL INDEX I I2OR / SCIENCE LIBRARY INDEX / Google Scholar I Academic Keys/ ROAD Open Access I Academic Resources / Scientific Indexing Services / SCIPIO / JIFACTOR

What are the characteristics of poor and good lesson planning?

Speaking about a good versus a bad lesson plan, any teacher would wonder about characteristics which make a difference. The answers to this question reflect the opinions of more than one hundred teachers who participated in several teacher training seminars between the years 2009 and 2013.

The respondents are teachers from military institutions from different European countries. The answers are listed starting with characteristics of good lesson plans, followed by the bed ones as they are described by teachers.

A good lesson plan:

- the focus is on learners

- starts with a sense of purpose

- keeps the teacher and students on track

- achieves the objectives

- helps teachers to avoid

"unpleasant" surprises

- provides a logical sequence

- encourages reflections, refinement and improvement

- enhances student achievement

- contains a variety of activities of different kinds

- matches activities to learning objectives

A bad lesson plan:

- the focus is on the teacher

- is written independently of the class

- assumes all students have the same pace

- is a source of frustration for the teacher and the students

- Assumes that because the students have done something by following

- instructions learning has taken place

- does not provide a clear link between aims and objectives

- the objectives are not met

- there is no connection to prior lessons

When asked to think of possible questions they could ask themselves before planning a lesson, the respondents came with the following questions:

- What is the main topic of the lesson?

- How can I arouse students' interest?

- How can I challenge students?
- How much should I review what the students already know?

- What are the objectives of the lesson?

- What vocabulary do I want to teach them?

- How can I explain the activities?

- How much detail do I need on my plan?

- What order should I teach the activities?

- What problems might I have?

Trainees were then provided with a set of 6 model lesson plans and were asked to compare and contrast them, to retain the elements which were considered positive and to design their own lesson plan based on the models given. They all agreed that the following components are to be included in a good plan:

- Content: This is a statement that relates to the subject-matter content (a concept or a skill), e.g. I want my students to be able to ... / to understand ....

- Prerequisites: Indicate what the students must already know or be able to do in order to be successful in the lesson.

- Instructional Objective: Indicate what is to be learned (in terms of what an individual student will do, not what the group will do).

- Instructional Procedures: Description of what you will do in teaching the lesson (introduction, instructional techniques, closure).

- Materials and Equipment: List all materials and equipment to be used by both the teacher and learner.

- Assessment / Evaluation: Describe how you will determine the extent to which students have attained the instructional objective.

- Follow-up Activities: Indicate how other activities / materials will be used to reinforce and extend this lesson (homework, assignments, projects, etc).

- Self-Assessment: To be completed after the lesson is presented. Focus on the strengths and the areas of needed improvement.

Trainees also discussed the most common mistakes in writing lesson plans. They all agreed that the most important ones are as follows: 
"Mircea cel Batran" Naval Academy Scientific Bulletin, Volume XIX - 2016 - Issue 2

The journal is indexed in: PROQUEST / DOAJ / Crossref / EBSCOhost / INDEX COPERNICUS / DRJI / OAJI I

JOURNAL INDEX I I2OR / SCIENCE LIBRARY INDEX / Google Scholar / Academic Keys/ ROAD Open Access I

Academic Resources / Scientific Indexing Services / SCIPIO / JIFACTOR

- $\quad$ The objective of the lesson is vague and does not specify what the student will actually do that can be observed.

- The lesson assessment is disconnected from the behavior indicated in the objective. An assessment in a lesson plan is simply a description of how the teacher will determine whether the objective has been accomplished. It must be based on the same behavior that is described in the objective.

- $\quad$ The prerequisites (what a student needs to know or be able to do to accomplish the lesson objective) are not specified or are inconsistent with what is actually required to succeed with the lesson. It is not easy to determine what is required, but it is necessary. According to some research, as much as $70 \%$ of learning is dependent on students having the appropriate prerequisites.

- The instruction of the teacher is not efficient for the level of intended student learning. Efficiency is a measure that means getting more done with the same amount of effort or the same amount with less effort.

- The student activities do not contribute in a direct and effective way to the lesson objective. Students should not do activities just to keep them busy. Whatever they do, it should contribute in a direct way to their accomplishing the lesson objective.

- The materials specified in the lesson are extraneous to the actual described learning activities.

As a last activity, in the light of what was discussed during the session, trainees were asked to come up with a model that could be used when writing a lesson plan. These are the elements they decided to include:

\section{Topic: \\ Objectives: \\ 1. \\ 2. \\ 3.}

LESSON PLAN:

Materials needed

New vocabulary:

Warm-up: (time to be mentioned)

Presentation: (time to be mentioned)

Practice: (time to be mentioned)

Evaluation: (concurrent with last part of practice)

Summary (and expansion) (time to be mentioned)

Application: (after class)

Contingency plan

Self-evaluation comments

\section{BIBLIOGRAPHY}

[1] Scrivener, J.,Learning Teaching, Macmillan Books, 2011

[2] Thornbury, S., An A to Z of ELT, Macmillan Books, 2006.

[3] *** Methodology in Language Teaching, OUP, 2002

[4] http://www.scholastic.com/teachers/article/new-teachers-guide-creating-lesson-plans 